\title{
Hegemonic Practices of Upperclassmen to Freshmen Within College Life
}

\begin{abstract}
Muhammad Syukur
Department of Sociology Education, Faculty of Social Science, State University of Makassar, 90222 Makassar, Indonesia; m.syukur@unm.ac.id; syukurmuhammad10@gmail.com
\end{abstract}

\section{ARTICLE INFO}

\section{Publication Info:}

Research Article

How to cite:

Syukur, M. (2019). Hegemonic

Practices of Upperclassmen to

Freshmen Within College Life.

Society, 7(2), 71-82.

DOI : $10.33019 /$ society.v7i2.112

Copyright (C) 2019. Owned by Author(s), published by Society

\section{OPEN Access c) (1) (-)}

This is an open access article.

\section{License: Attribution- \\ NonCommercial-ShareAlike (CC BY-NC-SA)}

Received: November 4, 2019; Accepted: November 18, 2019; Published: December 3, 2019;

\begin{abstract}
The research aims to explain: 1) Forms of hegemonic practices of upperclassmen to freshmen in college life at the State University of Makassar and 2) Levels of hegemonic practices of upperclassmen to freshmen at the State University of Makassar. This research is qualitative descriptive with snowball sampling technique used to determine the participants which consist of 25 upperclassmen and 20 freshmen class of 2018 and 2019 academic year. Data collection methods included observation, interview and documentation. Data analysis technique consists of three stages, namely: data reduction, data presentation and conclusion drawing. Data verification was conducted through observation perseverance and source and time triangulation. The results show that 1) forms of hegemonic practices of the upperclassmen to freshmen at the State University of Makassar include agreement, domination and intellectual leadership and moral and 2) the level of hegemony conducted by the upperclassmen at the State University of Makassar is in the decadent hegemony level. Relationship between upperclassmen and freshmen is good but only few freshmen who established intimacy. There is awkwardness between the upperclassmen and the freshmen during interaction. Freshmen are active in supporting the upperclassmen in student clubs at the department, faculty as well as university levels. It is because the freshmen feel reluctant if they do not carry out the upperclassmen direction. In addition there is also a sense of compulsion due to sanction used by the upperclassmen.
\end{abstract}

$\begin{array}{ll}\text { Keywords: } & \text { Hegemonic Practices; Hegemony; State } \\ & \text { University of Makassar; Students; } \\ & \text { Upperclassmen }\end{array}$

Copyright (C) 2019. Owned by Author(s), published by Society. This is an open-access article under CC-BY-NC-SA license. https://doi.org/10.33019/society.v7i2.112 


\section{Introduction}

Hegemony is inevitable in human life; it exists in political, economic, social, law, or education. This symptom occurs naturally since the order of human life is always as commanders and followers. Anyone can practice hegemony to reach their respective goals. In education, its practices are commonly found in schools, colleges or universities among students; upperclassmen to freshmen. According to Gramsci (1999), it is not only to create a collective will, but new conception of the world or Weltanschauung. For him, hegemony has no unconscious basis. This is contrast to the dictatorship as a form of domination which combines power and agreement without the power lost, and where the power itself is the object of consent. In short, hegemony is an agreement protected by coercive weapons.

A number of researchers studied about cultural hegemony in schools and they suggests to understand various cultural backgrounds as well as relevant pedagogy culturally (Scherff \& Spector, 2010), responsive teaching culturally (Gay, 2000), and multicultural instructions (Taylor \& Sobel, 2011). The expert views have valuable contributions in providing a significance framework to understand and solve cultural problems in multicultural backgrounds at schools.

Syafiie (2007) had conducted the study of violence in educational institution on case study of IPDN (Institute of Governance of Home Affairs) students where he found that ten incidents acted by upperclassmen to freshmen led to death occurred from 1994 to 2005. Marijan \& Fitrianto (2013) studied about relationship of upperclassmen and freshmen to investigate the anatomy of violence among university students in Makassar. The study found that violence is just affirmative action of identity among student class standings. Other references on student violence actions are also related to their perception as agents of changes and their social and political responsibilities to secure country condition.

As actors, upperclassmen usually stand themselves in experiencing and recognizing students of college life and they also play an important role in sharing their knowledge to their freshmen. The successful foster of freshmen character depends on how upperclassmen influence their freshmen to follow the upperclassmen will which is known as hegemony circle.

Upperclassmen always transform the dominant ways of thinking in which a concept of reality is disseminated in society both institutionally and individually; (ideology) dictates all tastes, moral habits, religious and political principles as well as all social relations, especially in term of intellectuality and morality (Patria \& Arif, 1999). In general, upperclassmen instill their mindset and experience to foster freshmen character about college life. Through the hegemony practice carried out by upperclassmen causes their freshmen considering the flow should occur. Ideally, as educated people, upperclassmen must instill an educational mindset for their freshmen. The purpose of the activities carried out by upperclassmen in coaching new students is to attract their attentions or direct the things that focus upperclassmen that are expected that the student is not only intellectual, but also emotionally intelligent. In addition, this hidden mastery in influencing the freshmen used as a tool by upperclassmen to instill various values that has lived on the campus. The values conveyed are good values of religious values, courtesy, struggle and sacrifice of students.

Ideally, upperclassmen should serve as models for freshmen in terms of: first, deepening and developing themselves in the field of science they pursue so they can have greatest intellectual abilities; the second, becomes a bridge between the theoretical world and the empirical world or able to find solutions to the problems of life in accordance with their scientific discipline; the three, agents of change.

The facts that occur in the field show that there is a hegemonic action committed by upperclassmen to freshmen. This condition is such upperclassmen always involved freshmen in

Copyright (C) 2019. Owned by Author(s), published by Society. This is an open-access article under CC-BY-NC-SA license.

https://doi.org/10.33019/society.v7i2.112

72 
various demonstration action activities. Upperclassmen instill in the freshmen mindset that the duty of a student is to take part in demonstrations. Freshmen are often punished for violating upperclassmen rule in the form of push-ups, squatting, lying down and other physical punishments. Upperclassmen also often ask freshmen to bring something like chocolate, wafers, etc. that have nothing to do with their study program. The flow of thought and actions of these upperclassmen is naturally accepted by freshmen so that they only follow the wishes of upperclassmen.

Likewise, various activities of other student organizations that bind freshmen to take part in accepting in upperclassmen student environment. Activities that bind freshmen certainly cannot be separated from the practice of hegemony carried out by upperclassmen. The activities carried out make freshmen willing to get involved in various activities whatever their form. Even many freshmen are consent to follow the process and make it a top priority compared to lecture activities. Though ideally as a student known as an Agent of Moral should avoid things those contradict with the ethics as student and call for kindness. The practice of hegemony to freshmen can continue to last without the awareness of the oppressed, due to enable freshmen to show the oppression they are receiving, even in its clearest form.

Based on these problems, this research investigated concepts and levels of hegemony practices by upperclassmen to freshmen at State University of Makassar.

\section{Literature Review}

\section{A. The Theory of Hegemony}

The theory of hegemony is one of prominent theories in the $20^{\text {th }}$ century. Antonio Gramsci, as the main character of the hegemony theory, was born in the $19^{\text {th }}$ century precisely in 1891. The theory has roots in the tradition of Karl Marx's thought. The idea of hegemony was first introduced in 1885 by Russian Marxists, especially by Plekhanov in 1883-1984. The idea was developed as part of a strategy to overthrow Tsarism. The term shows the hegemonic leadership that must be formed by the proletariat, and its political representatives, alliances with other groups, including some bourgeois critics, peasants and intellectuals attempt to end the Tsarist police state (Bocock, 2007).

Gramsci developed hegemony concept of marx and criticized Marxist ideas about the superstructure of society (Gramsci, 1999). Superstructures are culture, institution, power formation, and rituals established by a community base which is influenced by the forces of economic production. Gramsci responded to the Marxist concept by creating a historical block, that the recognition of the community base and the superstructure worked together symbiotically (Buckel \& Fischer, 2009). The two main components that comprise the historical block structure; First, civil society is a personal aspect of the structure consisting of churches, educational institutions, clubs, and the media. These are cultural and intellectual pieces. Second, political society is a public aspect consisting of government, military, police, and the justice system (Gramsci, 1999). This phenomenon is influenced by the economy. Gramsci also highlighted the interrelationships between the two which comprise the entire structure of society.

Related to power and its formation, Foucault (2002) also discusses the relationship between power and knowledge. Foucault (2002) abandons the old notion that views that knowledge is only possible to develop outside the realm of power. For Foucault, there is an interconnected relationship between knowledge and power. There is no practice of exercising power that does not generate knowledge and there is no knowledge in which it does not contain power relations. 
Power is exercised through certain regulations which influence one another. For Foucault, power does not come from outside but inside of organization. Power exercises its role through a series of certain rules and systems to produce a kind of power chain. It is not just about controlling people physically and dictatorships. In modern society, power works in a pattern of normalization, that is, the power is disguised, hidden and covered up that it seems invisible. Power no longer works through oppression and physical strength. Power is exercised by strengthening regulations that are carried out and obeyed voluntarily in an organization, agency or country.

Furthermore Gramsci argues that hegemonic practices can be developed, when the dominant social group must utilize both components (Gramsci, 1999). If personal power is rejected, then public power must be exercised to ensure that supremacy is maintained and vice versa (Litowitz, 2000). Whereas Simon (1999), hegemony is a means to understand society with the aim to change it. The purpose of the hegemony is to attract the attention of the community or direct the things that are focused by the hegemony.

According to Hartijo (2009), there are several important ideas related to the concept of hegemony including:

1) In hegemony, the dominant group over subaltered group to accept the moral, political and cultural values of the dominant group (in this context the ruling party or the ruling group);

2) Hegemony is accepted as something natural, so that the ideology of the dominant group can spread and be practiced;

3) The values and ideologies are fought for and defended by the dominant party in such a way that the dominated party remains silent and obedient to the leadership of the ruling group;

4) Hegemony is a strategy to maintain dominant powers.

\section{B. Hegemony in Education}

Through education, the elites can produce and promote their ideologies that justify their position by making their beliefs seem general (McDonald \& Coleman, 1999). The upperclassmen, especially those who join in student organization are categorized as elites in freshmen relations. Bourdieu (1990), argues that symbolic violence is related to the relations of power possessed by individuals and their relation to structures and systems that perpetuate such power. Bourdieu uses this concept to explain the mechanism used by upper class groups that dominate the social structure of society to impose their ideology, culture, habits or lifestyle on the lower class groups they dominate. Symbolic violence needs to be understood in relation to the concept of individual symbolic capital. Capital in Bourdieu's view is divided into social capital (wealth of individual relations), cultural capital (lifestyle, ways of acting and knowledge), and symbolic capital (the way an individual represents himself to the public).

According to Bourdieu (2009), symbolic capital is often as an accumulation of various other capital, namely cultural and social, thus giving individuals or certain social groups the power that allows them to dominate other social classes. Symbolic violence occurs when dominant social actors implement social meanings and representations of reality that are internalized to other actors as something natural and legitimate, even the social meanings are then considered true by other actors. This process occurs through the mechanism of implanting understanding and world view of a reality continuously, until finally an idea is formed that it all should be like that.

Upperclassmen always promote ideologies that justify their position to win the trust of their freshmen. Once the dominant group's beliefs are engrained in both private and public aspects

Copyright (C) 2019. Owned by Author(s), published by Society. This is an open-access article under CC-BY-NC-SA license.

https://doi.org/10.33019/society.v7i2.112

74 
of society, they begin to be viewed as common sense. This process does not occur with flippancy but with manipulation and strategy (Litowitz, 2000). Members of society live and teach the dominant principles without explicit cognition. Because multiple institutions multiply hegemonic principles, members of society do not generally question the issues (Litowitz, 2000). The lower classes accept their social role and consent to the rules enforced by everyday institutions. Hegemony is, therefore, achieved through establishment of an organic link between civil and political societies (Gramsci, 1999).

Hegemony is gained by establishing consensus rather than oppressive force. There are three levels of hegemony proposed by Gramsci, namely Integral, decadent, and minimum hegemony. Gramsci (2013) explains that integral hegemony is characterized by mass affiliation approaching totality. Society shows a strong level of moral and intellectual unity. The relationship is not encompassed by contradictions and antagonisms both socially and ethically. Secondly is decadent hegemony, which is the condition of modern capitalist society, where bourgeois economic domination faces severe challenges. There is a potential for disintegration there. Through this potential nature it is intended that disintegration appears in hidden conflicts beneath the surface of social reality. In other words, even though the existing system has reached its needs or targets, the mentality of the masses is not really in harmony with the dominant thinking of the subject of hegemony. Therefore, cultural and political integration is easy to collapse. Such a situation is called a decadent hegemony. Thirdly is minimum hegemony. This is the lowest form of hegemony compared to the previous two forms. This is the situation in Italy in the period of unification until the middle of this century. Hegemony rests on ideological unity between the economic, political and intellectual elites that goes hand in hand with the reluctance of any mass interference in state life. Therefore, hegemonic groups do not want to adjust their interests and aspirations with other classes in society. The rules are maintained through the transformation of cultural, political, social and economic leaders' unification which is potentially contrary to the new state aspired by the hegemonic group.

Hegemony succeeded when the ruling class won the agreement, both actively and passively than its allies. Fontana (1993) states hegemony is basically understood as the difference in which dominant social groups shaped a permanent approval system.

\section{Research Methodology}

This research was conducted at the State University of Makassar for 14 months, from July 2018 to August 2019 using a constructivist paradigm with descriptive qualitative as method. The technique in determining participants used snowball sampling, for upperclassmen have served or are currently serving as administrators in student organizations starting at the level of department, faculty and university. While freshmen as participants were class 2018 and 2019. Based on data saturation there were 25 upperclassmen and 20 freshmen who were selected as research participants. Data collection techniques used were observation, interviews, and documentation. In-depth observations and interviews were conducted with participants at the student secretariat, boarding houses and campus areas.

Data were analyzed using an interactive analysis model from Miles and Haberman (1994). The data have been collected then processed and analyzed using qualitative analysis techniques under the following steps; data reduction, namely the process of selecting and focusing attention and simplification, abstracting and transformation of rough data contained in interview notes and observations obtained in the field; display data is a set of information that has been arranged that emerge the meaning possibility which can be reported in drawing conclusions; drawing conclusions and verification is done after the data is presented, described

Copyright (C) 2019. Owned by Author(s), published by Society. This is an open-access article under CC-BY-NC-SA license.

https://doi.org/10.33019/society.v7i2.112

75 
and given meaning with a logical interpretation. Conclusions are based on data presentation and data reduction. Data verification is conducted by method of observation, persistence and triangulation of sources and time (Moleong, 2014).

\section{Results and Discussion}

\section{A. Forms of Hegemonic Practices of Upperclassmen to Freshmen Within College Life}

The forms of hegemonic practices of upperclassmen to freshmen within college life at State University of Makassar are as follows:

\section{1) Willing Agreement (consent)}

Upperclassmen consent which part of hegemonic practices to predominance freshmen in organization awareness within college life. The upperclassmen use a variety of techniques to meet an active agreement in terms of freshmen awareness to support the organizational activities both in level of department and faculty. The form of consent relates to the domination of mind, critical thinking and affective abilities.

The results showed that, upperclassmen apply same technique in building their freshmen consent to involve in organization through socialization and persuasive approaches. The socialization is conducted by introducing student organizations from department to faculty levels at welcoming new students. Upperclassmen always use dialectic technique to introduce the background of the organization, functions, organizational structures and the benefits or experiences gained through organization. It aims to dominate freshmen cognition.

Upperclassmen dominate their freshmen minds by giving an understanding of extra and intra-college organizations as a place to seek knowledge and experience as much as possible. The process of how the discourse on organization at State University of Makassar takes place in a complex process. After dominated the minds, upperclassmen learn the critical ability of freshmen to measure their knowledge about organizations with the various experiences gained by upperclassmen. The source of upperclassmen power comes from the knowledge they have as long standing class in college. This phenomenon is relevant to the theory of power and knowledge from Foucault (2002) that power no longer works through oppression and physical strength. Power is exercised by strengthening the regulations that are carried out and obeyed voluntarily. The discourse put forward by the upperclassmen always controlled the minds of the freshmen, so they were helpless before the upperclassmen.

The persuasive approach is established using intense communication by inviting freshmen to gather intensively in campus areas such as parks, canteens, student organization office, parking lots, and other pleasant places available on campus. This action is conducted in order to gain more mass and unite their thoughts according to their expectations. The persuasive approach is to dominate the freshmen affective abilities to build their interests in joining organizational activities, especially intra-campus organizations. All of these things are justified by freshmen class of 2018 and 2019.

Freshmen always consent actively involved in various activities of student organizations and they consider it as important things to increase their experiences and insights. Freshmen also assume that it has become their responsibilities to take part and become members of student organizations at the level of department, Faculty, and University. The upperclassmen doctrines have become a culture to be involved in organizations to support the spirit of students as agents of change.

This phenomenon is consistent with Gramsci's premise stated that hegemony prioritizes ideas and does not merely use physical force. For Gramsci (2013), hegemony through consensus or agreement has indirectly emerged as an active commitment of the community based on 


\section{Hegemonic Practices of Upperclassmen to Freshmen Within College Life}

something legitimate or commonsense. Another case with the path of dominance that emphasizes coercion and strength, consensus or agreement to use leadership enforcement tools, such as education, religion, media, publishing, and others. The tool functions as a hegemonic ideology.

Subordinate groups that are controlled accept and approve the ideas and political interests of the group that controls them (Qomaruddin, 2017). The same problem was also raised further by Laclau \& Mouffe (2008), that the mastering group seemed to attempt to naturalize a form and meaning of the ruling group that was built on moral grounds and agreement by instilling ideologies and ideas that could be accepted without rejection. The hegemony of consent that they built entered through a cultural path that was built through the paradigm, reason, ideology, art and science they possessed.

\section{2) Domination}

Upperclassmen as dominant groups or more powerful groups while freshmen are considered as controlled groups. The socialization and persuasive approach in the form of agreement by upperclassmen can be achieved with the dominance of the upperclassmen as a group that is able to subdue them. Therefore, it can be said that the success of freshmen student approval is closely related to the success in creating dominance of upperclassmen. Based on the results of the study, it was found that the form of dominance by upperclassmen occurred through the imposition of certain obligations and control of freshmen.

The dominance can be viewed from the condition that upperclassmen have amount of more mass and the position of them is higher than freshmen compared to their experience in acknowledge college life. Upperclassmen have the power to pressure freshmen in participating of various student body activities and offer sanctions if they are absent from these obligations. Ideology infiltrated through the process of socialization by giving sanctions is an awareness that aims to make the desired ideas become the norm agreed upon by freshmen. The findings of this study are similar to the results of research (Christle et al., 2010; Noguera, 2003; Skiba \& Peterson, 2000) where students who cannot follow school rules receive penalties which often result in them being expelled from institutions due to lack of changes in their behavior over time to time.

Another form of dominance can be viewed from the control of upperclassmen on their freshmen. The control is done by follow-up after the freshmen follow the Basic Student Leadership Training (LDKM) activities. Control is intended to keep escorting freshmen to actively participate in every student activity both at the Study Program, Faculty, and University levels. This symptom is justified by freshmen in class 2018 and 2019 who acknowledge that there is a fear of sanctions used if there are compulsory activities directed at upperclassmen and then it is not implemented. Sanctions are often used for freshmen who do not follow the upperclassmen will, the sanctions are various such as push-ups, upperclassmen treats, and scolding in public.

Hegemony with the path of domination certainly uses the tools of violence and force. This hegemonic practices of upperclassmen who take cover behind the discourse of freshmen' obligation to be involved in student organizations. The discourse of obligation that is always rolled by upperclassmen to freshmen transforms into knowledge received by freshmen and has the effect of power to discipline freshmen to take part in the word upperclassmen. This phenomenon supports the theory and power and knowledge of Foucault (2002), that discourse always produces knowledge, and knowledge will produce power. The pattern of domination of this pathway legalizes violence in practice. The context of this understanding is where the 
political community is identified with the student body as a campus apparatus that has the authority of coercion. Hegemony in the form of domination is characterized by the use of force, violence, coercion, authority, tactics, and agitation.

Hegemony in the form of domination is also manifested through rules made unilaterally by upperclassmen. For example, if there is a meeting, the meeting hours refer to the hours that they have. If the upperclassmen come earlier in a meeting then the freshmen come late, then the upperclassmen will be angry. However, if the upperclassmen are late, then he sets the time in the hour according to the time of his attendance at the meeting. For example, if the agenda of the meeting is at 3:00 p.m., while the upperclassmen come at 3:30 p.m., then they set his watch to 3:00 p.m. freshmen do not dare to protest and only accept the situation as it is. Upperclassmen often schedule meetings when freshmen still have class schedules. But the upperclassmen never schedule meetings when they have class schedules. Upperclassmen, as a dominating class, always receive justification for their actions. The results of this study are relevant to the findings of Indra (2017) about government hegemony in setting unilateral rules towards market traders.

This phenomenon is also consistent with what was stated by Gramsci who views that domination is the beginning of the hegemony process. Someone is able to do anything, even able to make other people carry out his orders if he has a power or position (Gramsci, 1999). Upperclassmen that have long been standing on college life compared to freshmen are considered to have a higher position and have more power than freshmen.

Freshmen always consent to the actions of upperclassmen; however upperclassmen always seem with power and dominance. This relationship colors the campus life arena between upperclassmen and freshmen. The link between agreement and dominance in this arena is in line with the results of the study (Kartika Rizqiyah, 2018; Hannan and Abdillah, 2019; Lears, 2016). The approval arises from the existence of more power from upperclassmen to control. This reality is what makes upperclassmen dominate over freshmen, producing to hegemonic practices.

\section{3) Intellectual and Moral Leadership}

Upperclassmen techniques in dominating over freshmen are through moral and intellectual leadership. The results show that, the form of moral and intellectual leadership is used in the practice of upperclassmen hegemony, although this hegemonic form is only applied by a small portion of upperclassmen within college life at State University of Makassar. This leadership form is applied by performing good manner and intellectual personality to attract freshmen and make the upperclassmen as role model so freshmen can be led as their upperclassmen want to do for them.

Upperclassmen transform the symbolic violence to freshmen by inviting them to follow in his footsteps becoming a member of student organization. Upperclassmen often agitate and force freshmen to follow their desires. Agitation is manifested in the form of scaring or bluffing freshmen that the upperclassmen will not help them when they have academic problems. Freshmen as a dominated party then views the place of the upperclassmen is doing a right thing.

Dignity and self-esteem of upperclassmen are at stake if they transform knowledge to freshmen. It is this symbolic capital possessed by upperclassmen that triggers symbolic violence in freshmen. Symbolic capital owned by upperclassmen, does not stand alone, but is also supported by cultural capital in the form of knowledge and ways of acting that are more mature than freshmen. This practice is consistent with Bourdieu's (1990) view of the occurrence of 
symbolic violence. As a result, as a result freshmen as a lower class society, forced to accept, undergo, practice, and recognize that the upper class habitus (upperclassmen) is a proper habitus for them to follow.

Upperclassmen who always apply this form are inseparable from the upperclassmen that have positions at the top of organizations such as the Chair of the Department Association, the Senate Chair and the Chair of the Student Consultative Assembly (MAPERWA) at the Faculty and University level. Actors can appear as intellectual and moral leaders are those who have more control in a student organization. As an upperclassmen student who has an important role in shaping the character of freshmen, certainly aware that upperclassmen will be the central freshmen. Upperclassmen should show good examples in terms of behavior and intellectuals such as authority, ways of speaking, inviting freshmen to discuss scientific disciplines, increase knowledge and so on. The form of hegemony in the form is intended to perpetuate the hegemony process carried out by the upper class after using a form of domination and agreement.

This condition was approved by the freshmen class of 2018 as participants. All of them agreed that the upperclassmen set good examples in terms of attitudes such as authority, communication way, problem solvers for freshmen. The freshmen admitted that they were more interested in making a role model for upperclassmen who set positive examples such as in terms of academic achievement, communication skills, authority, and having broad insights. This moral leadership is supported by Gramsci's statement that leadership is one of the main conditions for reaching the top of the pyramid and winning power (Patria \& Arif, 1999).

Regarding intellectual domination, furthermore, Gramsci stated that all men are intellectuals, but not all men have in society the function of intellectual (Gramsci, 2013). In this research, the phenomenon only showed seven upperclassmen have intellectual and moral dominance. The seven students, one of them is the chair of Student organization of department, then two of them as the chair of the Faculty Student Executive Board (BEM), one of them as Chair of the Faculty Student Representative Council (MAPERWA), two Chairpersons of the University Student Executive Board (BEM), and one Chairperson of the Student Representative Council (MAPERWA) at the University level. The ability of the seven upperclassmen has the power to hegemonic the freshmen since they have above-average academic abilities, excellent communication skills, broad insight, and good personality during interactions.

\section{B. Level of Hegemonic Practices of Upperclassmen to Freshmen Within College Life}

The level of hegemonic practices by upperclassmen within college life at State University of Makassar can be viewed from the relationship established between upperclassmen and freshmen as a result of the form of hegemony carried out by upperclassmen. The results of the study showed that the level of hegemony conducted by upperclassmen towards freshmen in instilling awareness by the goals of the upperclassmen. at a decadent hegemony level. This phenomenon can be seen from the relationship between the upperclassmen and their freshmen, although they are well-established, but only a few freshmen set up that familiarity. Interaction of some upperclassmen with freshmen still creates a sense of awkwardness. This situation shows the absence of such a strong relationship or harmony between the class that is controlled and the class that is in control. freshmen are active in supporting a number of activities in student organizations at the level of study programs, faculties, and universities even though freshmen are not in line with the activities they support because they feel reluctant if they do not carry out their upperclassmen directives. The feeling of being reluctant forced some of the activities that he participated on the basis of fear. In addition, some freshmen do not show a

Copyright (C) 2019. Owned by Author(s), published by Society. This is an open-access article under CC-BY-NC-SA license.

https://doi.org/10.33019/society.v7i2.112

79 
good moral unity seen from freshmen who are unable to put good ethics towards their upper class.

This phenomenon is in line with Gramsci (1999) about the decadent hegemony, namely the existing system has reached its needs or targets, but the mentality of the masses is not really in harmony with the dominant thinking of the hegemony subject. Interactions that occur at this level show the potential for disintegration there (Patria \& Arif, 1999). Another explanation is also stated by Hartijo that the level of decadent hegemony occurs if the community is not in line with the existing leadership. Through these conditions, it is possible for the community to get another agreement that is not in line with the existing leadership. For some reason, other agreements seem to support the existing leadership (Hartijo, 2009). The results of the study did not find any variant forms of the level of integral hegemony and minimal hegemony as stated by Gramsci (1999).

\section{Conclusions}

The forms of hegemonic practices of upperclassmen to freshmen within college life at State University of Makassar are dominance, willing agreement, intellectual and moral leadership. First, hegemony in the form of consent is obtained through two ways namely socialization and persuasive approach. Second, hegemony in the form of dominance is done by emphasizing the obligation of several activities and control for junior students who want to continue to exist in student institutions both at the Study Program, Faculty and University level. In terms of behavior and intellectuals such as above average academic achievement, upperclassmen authority, speaking skills, have broad insights, so that a good upperclassmen image is built in the eyes of junior students and is able to perpetuate the upperclassmen hegemony process.

The level of hegemony practices by upperclassmen to their freshmen within college life at State University of Makassar is at the level of decadent hegemony. This phenomenon can be seen from the relationship between the upperclassmen and the freshmen although they are well established, but only a few freshmen have established in intimacy. In addition, there is still a sense of awkwardness created by the freshmen as well as a sense of compulsion in participating in some activities for reasons of fear of being sanctioned for upperclassmen.

\section{Acknowledgement}

I would like to express my special thanks of gratitude to Rector of State University of Makassar for permitting me to conduct this research at State University of Makassar. I also like to express my sincere appreciation to participants for the time and information during collecting this research data.

\section{References}

Bocock, R. (2007). Pengantar Komprehensif untuk Memahami Hegemoni. Yogyakarta: Jalasutra. Bourdieu, P. (1990). An Introduction to the Work of Pierre Buordieu. London: Macmillan Press Ltd.

Bourdieu, P. (2009). (Habitus x Modal) + Ranah = Praktik. Yogyakarta: Jalasutra.

Buckel, S., \& Fischer-Lescano, A. (2009). Gramsci reconsidered: hegemony in global law. Leiden Journal of International Law, 22(3), 437-454.

Christle, C. A., Jolivette, K., \& Nelson, C. M. (2010). Breaking the School to Prison Pipeline: Identifying School Risk and Protective Factors for Youth Delinquency. Exceptionality: A Special Education Journal, 13(2), 69-88. 
Fontana, B. (1993). "Hegemony and Power: on the Relation Between Gramsci and Marchiavelli". American Political Science Review, 88(4).

Foucault, M. (2002). The Archaelogy of Knowledge. London and New York: Routledge.

Gay, G. (2000). Culturally Responsive Teaching: Theory, Research \& Practice. New York: Teachers College Press.

Gramsci, A. (1999). Selection From the Prison Notebooks of Antonio Gramsci Edited and Tranlated by Hoare, Quentin and Smith, Geoffrey. Nowell. London: ElecBook.

Gramsci, A. (2013). Catatan-Catatan dari Penjara. Yogyakarta: Pustaka Pelajar.

Hannan, A., \& Abdillah, K. (2019). Hegemoni Religio-Kekuasaan dan Transformasi Sosial Mobilisasi: Jaringan Kekuasaan dan Keagamaan Kyai dalam Dinamika Sosio-Kultural Masyarakat. Sosial Budaya. 16(1), 9-24.

Harjito. (2009). Hegemoni Gramsci. MAJALAH LONTAR, 23(4).

Kartika Rizqiyah, F. (2018). Hegemoni “Kuningisasi” bagi Pegawai Negeri Sipil (PNS) Dinas Pemerintah Daerah Kabupaten Jombang. Paradigma, 6(1).

Laclau, E., dan Mouffe, C. (2008). Hegemoni dan Strategi Sosialis: Post Marxisme dan Gerakan Sosial Baru. Yogyakarta: Resist Book.

Lears, T. J. (2016). “The Concept of Cultural Hegemony: Problems and Possibilities". The American Historical Review, 90(3).

Litowitz, D. (2000). Gramsci, Hegemony, and the Law. Brigham Young University Law Review, 515-551.

Marijan, K., \& Fitrianto, H. (2013). Anatomi Kekerasan Mahasiswa di Makassar. Jurnal Review Politik. 3(1), 1-27.

McDonald, P., \& Coleman, M. (1999). Deconstructing Hierarchies of Oppression and Adopting A 'Multiple Model' Approach to Anti-Oppressive Practice. Social Work Education, 18(1), 19-33.

Miles, M. B., \& Huberman, A. M. (1994). Second Edition. Qualitative Data Analysis. Thousands Oaks London, India: Sage Publication.

Moleong, L. J. (2014). Metodologi Penelitian Kualitatif. Bandung: Remaja Rosdakarya.

Noguera, P. A. (2003). Schools, Prisons, and Social Implications of Punishment: Rethinking Disciplinary Practices. Theory into Practice, 42(4), 341-350.

Patria, N., Arief, A., \& Prasetyo, E. (1999). Antonio Gramsci: Negara \& Hegemoni. Yogyakarta: Pustaka Pelajar.

Qomaruddin. (2017). “Analisis Pemikiran Antonio Gramsci tentang Hegemoni Menurut Konsep Pendidikan Islam”. Jurnal Ilmu Pendidikan Islam, 17(1).

Sari, P., \& Indra, C. A. (2017). HEGEMONI PEMERINTAH TERHADAP PEDAGANG PASAR:(Analisis Dominasi Pemerintah Pasca Revitalisasi Pasar Kite Sungailiat Menurut Antonio Gramsci). Society, 5(1), 1-11.

Scherff, L., \& Spector, K. (2010). Culturally Relevant Pedagogy: Clashes and Confrontations. New York: Rowman \& Litlefield Education.

Simon, R. (1999). Gagasan Gagasan Politik Gramsci. Yogyakarta: Pustaka Pelajar.

Skiba, R. J., \& Peterson, R. L. (2000). School discipline at a crossroads: From zero tolerance to early response. Exceptional Children, 66 (3), 335-347.

Syafiie, I. K. (2007). Maju Tak Gentar: Membongkar Tragedi IPDN. Jakarta: Gema Insani Press. Taylor, S.V., \& Sobel, D. M. (2011). Culturally Responsive Pedagogy: Teaching Like Our Students' Lives Matter. London: Emerald Group Publishing Limited. 
Woolcock, J. A. (1985). Politics, Ideology, and Hegemony in Gramsci's Theory. Social and Economic Studies, 199-210.

\section{About The Author}

Muhammad Syukur obtained his Ph.D. in Rural Sociology at IPB University, 2013. The author is an Associate Professor and Head of Department of Sociology Education, Faculty of Social Science, State University of Makassar, Indonesia. His researches are mainly in Rural Sociology and Sociology of Education. 